ADDIN, Volume 13, Number 2, August 2019

\title{
Pesantren and Disability: the Dynamics of Islamic Boarding School in Accommodating Children with Disabilities
}

\section{Nur Ghufron}

Institut Agama Islam Negeri (IAIN) Kudus, Indonesia emnurghufron78@gmail.com

\section{Amin Nasir}

Institut Agama Islam Negeri (IAIN) Kudus, Indonesia aminnasir93@gmail.com

\section{Abstract}

Islamic Boarding School is one of the Islamic educational institutions in Indonesia, Islamic boarding school is a religious education institution that has its distinctiveness and is different from other education. Education in Islam, education, da'wah, community development, and other similar education. In general, Islamic boarding schools accept normal Santri in terms of ability. However, there are Islamic boarding schools that only accept students who have special needs. The purpose of this study was to study how disability education in al-Achsaniyyah Islamic Boarding School. This study used descriptive qualitative method. This study involved six informants, consisting of one main informant, and five supporting informants who worked on supplementing the data. The selection of informants is based on purposive sampling. Data exploration was carried out by in-depth interviews, nonparticipant observation, and field notes. The validity of the study was carried out by the method of data triangulation, namely by checking the facts by comparing them with various sources, methods, and theories. The results showed that al-Achsaniyyah Islamic Boarding School is a special boarding school for people 
with disabilities located in Kudus, Central Java. Like other huts, Pondok al-Achsaniyyah Kudus also has elements in the form of Kyai, dormitories, mosques as centers of worship, schools and the presence of Santri. It's just that students in al-Achsaniyyah Kudus Islamic Boarding School are autistic.

Keywords: Pesantren, Children, Disability.

\section{Abstrak}

PESANTREN DAN DISABILITAS: DINAMIKA PONDOK PESANTREN DALAM MENGAKOMODASI ANAK-ANAK DISABILITAS. Pondok pesantren adalah salah satu lembaga pendidikan Islam yang ada di Indonesia. Pesantren adalah lembaga pendidikan keagamaan yang mempunyai kekhasan tersendiri dan berbeda dengan pendidikan lainnya. Pendidikan di pesantren meliputi pendidikan Islam, dakwah, pengembangan kemasyarakatan, dan pendidikan lainnya yang sejenis. Pada umumnya, pondok pesantren menerima santri yang normal dari segi kemampuan. Namun demikian, terdapat pondok pesantren yang justru hanya menerima santri yang berkebutuhan khusus. Tujuan penelitian ini adalah untuk mengetahui bagaimanakah pendidikan disabilitas yang berada di Pondok Pesantren al-Achsaniyyah Kudus. Penelitian ini menggunakan metode kualitatif deskriptif. Penelitian ini melibatkan enam informan, yang terdiri atas satu informan utama dan lima informan pendukung yang berfungsi sebagai pelengkap data. Pemilihan informan didasarkan atas purposive sampling. Eksplorasi data dilakukan dengan wawancara mendalam, observasi non-partisipan, serta catatan lapangan. Validitas penelitian dilakukan dengan metode triangulasi data, yaitu dengan check and re-check temuan fakta dengan cara membandingkannya dengan berbagai sumber, metode, dan teori. Hasil penelitian menunjukkan bahwa Pondok Pesantren al-Achsaniyyah adalah sebuah pondok pesantren khusus bagi penyandang disabilitas yang berada di Kudus, Jawa Tengah. Sebagaimana pondok lainnya, Pondok Pesantren al-Achsaniyyah Kudus juga mempunyai elemen berupa kiai, asrama tempat tinggal, masjid sebagai pusat tempat ibadah, sekolah, dan adanya santri. Hanya saja santri di Pondok Pesantren al-Achsaniyyah adalah penyandang autis.

Kata Kunci: Pesantren, Anak, Disabilitas. 


\section{A. Introduction}

Every human being has the most basic human rights to get an education, including children with disabilities. The mandate that every citizen has an equal opportunity to obtain education is contained in the 1945 Constitution Article 31 Paragraph 1, which is emphasized in RI Law No. 20 of 2003 Concerning the National Education System, as well as in the Minister of National Education Regulation No. 70 of 2009 concerning Inclusive Education for Students Who Have Disabilities and Have Potential Intelligence and/or Special Talents. According to Sunardi and Sunaryo ${ }^{1}$, the recognition of the right to education for every citizen is also reinforced in the Universal Declaration of Human Rights (1948), World Declaration on Education for All (1990), UN Standard Rules on Equal Opportunities for Persons with Disabilities (1993), Salamanca Statement and UNESCO Framework for Action (1994), Disability Act (1997), Dakar Framework for Action (2000) and Declaration of the International Congress of Children (2004).

The importance of attention to the education sector in development is nothing but because education can create and provide quality human resources so that they can contribute to the smooth development of national development. No exception for children with special needs such as, visually impaired, deaf, mentally retarded, disabled, disabled, children with learning difficulties and other disabilities also have the same opportunity to get an education.

However, the reality shows that there are still many children with disabilities who have not yet attained education. This is because the negative stigma is aimed at people with disabilities in Indonesian society. Indonesian society views people with disabilities as something troublesome. Some even consider their existence

${ }^{1}$ Sunardi and Sunaryo, "Manajemen Pendidikan Inklusif: Konsep, Kebijakan, dan Implementasinya," Jurnal Asessmen dan Intervensi Anak Berkebutuban Kbusus 10, no. 1 (2011): 184-200. 
as a family dishonor, the source of the problem, to the curse of sin. Persons with disabilities are also considered as people who cannot do anything and need to be merciful and helpful. Persons with disabilities are considered as useless people, even if getting an education is a waste of money and energy.

Negative stereotypes and mythology create injustice rooted in persons with disabilities. ${ }^{2}$ This injustice is then reflected through negative feelings and behaviors, which hinder social participation, education, and work-related. That is due to the inherent assumption that they are not able to control their desires, emotions, and lack of ability to socialize with others. ${ }^{3}$ Talking about education in Indonesia is inseparable from discussions on pesantren. Pesantren is the oldest type of Islamic educational institution and has long been rooted in the culture of Indonesian society. The pesantren is a center for the study and deepening of the treasury of Islamic sciences and at the same time as a center for the propaganda movement to spread Islam in the community. The pesantren is also known as the guardian of Islamic orthodoxy. Islamic boarding schools are unique educational institutions, not only because of their very long existence, but also because of the culture, methods, and networks adopted by these religious institutions. Besides that, Islamic boarding schools are also the original (indigenous) education system in Indonesia. ${ }^{4}$

Islamic boarding school is one of the Islamic educational institutions in Indonesia, Islamic boarding school is a religious education institution that has its characteristics and is different from other education. Education in pesantren includes Islamic education, da'wah, community development, and other similar education. The students at the pesantren are called "santri" who generally stay at the

${ }^{2}$ A.H. Shapiro, Everybody Belongs (UK: Routledge, n.d.).

${ }^{3}$ P.J. White, M.J. Jackson, V. Gordon, "Implicit and Explicit Attitudes toward Athletes with Disabilities," Journal of Rehabilitation 72, no. 3 (n.d.): 33-40.

${ }^{4}$ A. Mustaqim, "Menggagas Pesantren Transformatif," Aula, no. 9, (n.d.). 
pesantren, referred to as "pondok". From here the term "Islamic Boarding School". ${ }^{5}$

In general, Islamic Boarding Schools accept normal santri in terms of ability. However, there are Islamic Boarding Schools that only accept students with special needs, namely autism. The boarding school is al-Achsaniyyah Kudus Islamic Boarding School. al-Achsaniyyah Kudus Islamic Boarding School is a boarding school specifically for people with autism (autistic students) located in Kudus, Central Java. Considering that the Autism al-Achsaniyyah Islamic Boarding School in Kudus is different from other Islamic Boarding Schools, this study seeks to uncover the model of the Islamic Boarding School.

\section{B. Discussion}

\section{Religion and Disability}

There is a multidimensional relationship between disability and religion. Religion plays an important role in the lives of millions of people around the world. Eighty percent of the world's population is identified as adherents of one of the world's big or small religious traditions. Like others in societies around the world, people with disabilities have been directly or indirectly influenced by religion throughout history. Both physical and mental healing has been an integral part of religion throughout the history of humanity.

Despite the relationship between religion and disability, the literature on the impact of religious beliefs or practices on persons with disabilities, however, is rarely spread across various fields of study in the field of health and disability. From all research in the fields of religion and health, there are only a few studies on religion, religious activities, prayer and health in populations with disabilities and especially mental retardation. Since the 1950s,

\footnotetext{
${ }^{5}$ Departemen Agama RI Direktorat Jenderal Kelembagaan Agama Islam, Pondok Pesantren dan Madrasah Diniyah (Jakarta: n.d.).
} 
several researchers have examined the role of religion in the lives of parents and caregivers with disabilities. The researchers have received consistent evidence that religious orientation plays an important role as a coping strategy in the lives of these people. For example, the belief that disability is a form of divine punishment does not help the individual, whereas the belief that disability is part of God's purpose (or interpreted in other ways to inspire experience with meaning and purpose) can prove useful. ${ }^{6}$

Still according to Ghaly said that other research that specifically discusses people with disabilities and the influence of religion on health and well-being. ${ }^{7}$ The main purpose of this research is to provide information about the cultural background of people who have faith as one of the aspects of culture. Focusing on trust as an important cultural aspect, this study provides overall simple information about the views of religions such as Christianity, Hinduism, Islam, Brua and Winti regarding mental disability.

Other than that, the discussion about religion and disability is inseparable from the explanation of the text of the Holy Qur'an and also the Hadith as a source of religious teachings and sources of law. As Chaim and Miles argued, ${ }^{8}$ Blanks and Smith ${ }^{9}$ explained that disability is a normal aspect of human life, both according to the Qur'an and Islamic law. Therefore, they have the same position in religious rights and the obligation to practice religious teachings.

${ }^{6}$ M. Ghaly, "Islam and Disability: Perspectives in Islamic Theology and Jurisprudence” (Leiden University, 2008).

${ }^{7}$ Ghaly.

${ }^{8}$ V. Rispler-Chaim, Disability in Islamic Law (Dordrecht, The Netherlands: Springer, n.d.).

9 J.D. Blanks, A.B. Smith, "Multiculturalism, Religion, and Disability: Implications for Special Education Practitioners, Education, and Training in Developmental Disabilities," 44, no. 3 (2009). 
While according to Bazna and Hatab ${ }^{10}$ also Blanks and Smith's ${ }^{11}$ disability is something that is morally discussed with neutrality, disability is not a curse or a blessing from God, and disability does not represent a disorder in spirituality.

Besides, in the classical literature of Islamic law, there is still no specific discussion regarding disability fiqh which explains the obligations and rights of worship of persons with disabilities. However, contemporary scholars and academics began to study and explore Islamic literature to find a disability fiqh formula, as did Vardit Rispler-Chaim ${ }^{12}$ in his book Disability in Islamic Law. In general, there is no different for every Muslim, both with a disability or a non-disabled, to carry out the obligation to worship God.

\section{Education and Disability}

Children with disabilities disproportionately are often denied their right to education, which reduces their ability to enjoy their citizenship rights, find work and take on valuable roles in society. UNICEF $^{13}$ survey data shows that households from 13 vulnerable and middle-income countries show that children with disabilities between the ages of 6-17 years are significantly less likely to be enrolled in school than their non-disabled peers. Even though children with disabilities are not given equal access to school, the government will not be able to achieve basic education for all.

While in Indonesia, the practice of implementing education of persons with disabilities is carried out with special education or

${ }^{10}$ T.A. Hatab and M.S. Bazna, "Disability in the Qu'ran: the Islamic Alternative to Defining, Viewing, and Relating to Disability," Journal of Religion, Disability, and Health, n.d.: $5-24$.

${ }^{11}$ J.D. Blanks, A.B. Smith, "Multiculturalism, Religion, and Disability: Implications for Special Education Practitioners, Education, and Training in Developmental Disabilities," 44, no. 3 (2009).

${ }^{12}$ Rispler-Chaim, Disability in Islamic Law.

${ }^{13}$ UNICEF, "The State of the World's Children with Disabilities", Executive Summary, in https://violenceagainstchildren.un.org/sites/violenceagainstchildren.un.org/ files/documents/other_documents/sowc_2013-executive_summary_en_.pdf. 
separating children with disabilities from normal children and placed in special schools such as Special Schools (SLB) and some that are placed or shared with children. other normal or regular schools or often called inclusive schools. ${ }^{14}$

SLB educational institutions are educational institutions aimed at helping students with physical and/or mental, behavioral and social disabilities to be able to develop attitudes, knowledge and skills as individuals and community members in establishing reciprocal relationships with the social, cultural, and natural environment and can develop skills in the world of work or attend further education.

While inclusive education is education that includes all children together in a climate and learning process with appropriate educational services and accordance with individual needs of students without discriminating against children who come from ethnic backgrounds, social conditions, economic abilities, politics, family, language, geographical (remoteness) of residence, sex, religion, and differences in physical or mental conditions. Both of these models have their weaknesses and strengths. ${ }^{15}$

Studies in many countries have shown a strong relationship between poverty and disability, which in turn is related to gender, health and employment issues. Children with disabilities are often trapped in a cycle of poverty and exclusion. Girls are forced to care for their siblings instead of going to school, for example, or the whole family is stigmatized, so they are reluctant to report that there are children with disabilities or are reluctant to take them to the public. But the education of those who are ostracized or marginalized leads to poverty reduction.

14 “Manajemen Pendidikan Inklusif: Konsep, Kebijakan, dan Implementasinya."

${ }^{15}$ U. Firdaus, "Model Pembelajaran PAI Inklusi pada Peserta Didik Autis di SDLB Sunan Kudus” (Skripsi: UIN Walisongo Semarang, n.d.). 


\section{Characteristics of Islamic Boarding Schools}

Islamic boarding school is an institution that is widely praised by people, especially Muslim communities, as well as the existence of Madrasas and Islamic Schools in Indonesia. But at the same time often also get criticized and labeled as an institution that many "hinder" the progress of Islam. In the controversy about pesantren like that, it has indirectly placed pesantren as an institution that is important enough to always be considered and get a special view. A positive outlook will place the controversy as an opportunity to strengthen the role of the pesantren itself. ${ }^{16}$

In terms of terminology, it can be explained that pesantren education is a place where the external dimension (appreciation of birth) in Islam is taught in terms of its form and system originating from India. Before the process of spreading Islam in Indonesia, the system was generally used for Hindu education and teaching in its teaching. ${ }^{17}$

The word pesantren comes from the word Santri which is given the prefix "pe" and the suffix "an" which is due to the pronunciation of the word then changes to read "en" (pesantren), which is a term for the physical building or dormitory where the Santri are housed. The place is said in Javanese as a cottage or boarding house. The word Santri itself comes from the word cantrik, which means students of a receipt who also usually settle in a place called "padepokan". Islamic boarding schools have similarities with boarding schools in several ways, namely the presence of students (cantrik and santri), the presence of teachers (kiai), the existence of buildings (boarding schools and boarding schools), and finally the existence of teaching and learning activities. ${ }^{18}$

${ }^{16}$ Sri Haningsih, "Peran Strategis Pesantren, Madrasah, dan Sekolah Islam di Indonesia," 2008.

${ }^{17}$ H. Herman, "Sejarah Pesantren di Indonesia," al-Ta'dib, 2013.

${ }^{18}$ A. Muhakamurrohman, "Pesantren: Santri, Kiai, dan Tradisi," IBDA: Jurnal 
Islamic boarding schools first appeared in Indonesia in the $16^{\text {th }}$ century CE, namely in Ampel Denta under the care of Sunan Ampel. At that time, he was recruiting his students to spread Islamic teachings throughout the country, and some were even assigned to neighboring countries. From these Sunan Ampel students, mushrooming pesantren across the country. The climax was at the beginning of the middle of the $19^{\text {th }}$ century and the beginning of the $20^{\text {th }}$ century, at the time of Syekh Khalil Bangkalan. From the cold hands, he emerged the great Kiai of the archipelago which could later incubate other great Kiai. The climax, at that time in almost every sub-district town, in every village stood one boarding school or even more. In its journey, the classification of pesantren emerged in Indonesia based on the system or type of educational institution that is held. ${ }^{19}$

Pondok pesantren now expresses its gratitude and has the right to be proud because of the increasing attention from leaders and the community towards the world of Islamic education and Islamic Boarding Schools. This has evolved from an educational institution with an almost unrecognized existence even with the positive role it has played in the largest authentic Indonesian education system with a stronghold on people's hearts. The stereotypical opinion of the institution as traditional and dogmatic is no longer common, because it has succeeded in changing this misunderstanding ${ }^{20}$

According to Zamakhsyari, quoted by Muhammad Jamaluddin, the basic elements of the hut consisted of the hut, the mosque, the teaching of classical Islamic books, santri, and kiai. An Islamic boarding school is a traditional Islamic education hostel where the students live and study under the guidance of a (or more) teacher better known as "kiai". The boarding house for the

Kajian Islam, 2014.

${ }^{19}$ B.H. Sutrisno, "Sejarah Walisongo: Misi Pengislaman di Jawa," 2007.

${ }^{20}$ Gamal Abdul and Nasir Zakaria, "Pondok Pesantren: Changes and Its Future," 
students is in the pesantren complex where the kiai live, which also provides a mosque for worship, space for learning and other religious activities. ${ }^{21}$

In addition to the hostel, the mosque is an inseparable element with the pesantren because it is considered the most appropriate place to educate students, especially in the practice of five-time worship, sermons, and Friday prayers, and teach classical Islamic books. Another element of the pesantren is the teaching of classical Islamic books, especially the essays of scholars who embrace Syafi'iyah which is the only formal teaching given in the pesantren environment. The main objective of this teaching is to educate prospective scholars. The whole classics taught can be classified into eight groups: (a) NahwuSharaf (syntax-morphology); (b) Fiqh; (c) Usul Fiqh; (d) Hadith; (e) Tafsir; (f) Tawhid; (g) Sufism and Ethics; (h) Other branches such as Balaghah. The books include very short texts to texts that consist of thick volumes of hadith, tafsir, jurisprudence, ushul figh, and sufism. All of these can also be classified into three groups, namely: (a) basic books; (b) the books of intermediate behavior; (c) the big books. ${ }^{22}$

Other pesantren elements are santri. According to the understanding used in the pesantren environment, an alim can only be called a kiai if he has a pesantren and santri who live in the pesantren which he leads to study classical Islamic books.

The pesantren element conveyed by pesantren education practitioners referred to above refers to the integration between the Muslim system and the Islamic Boarding School system or Islamic Boarding School system. The two opinions above show

${ }^{21}$ M. Jamaluddin, "Metamorfosis Pesantren di Era Globalisasi," KARSA: Journal of Social, 2012.

${ }^{22}$ H.A.R. Makmun, "Pembentukan Karakter Berbasis Pendidikan Pesantren: Studi di Pondok Pesantren Tradisional dan Modern di Kabupaten Ponorogo," Cendekia: Jurnal Kependidikan, 2016. 
that there is still no adequate conclusion about the elements of pesantren that can portray all the dynamics of the development of pesantren, especially in recent times, where pesantren have developed in such a way as to follow the direction of world development and education in Indonesia.

In the regulation of the Minister of Religion No. 3/1979 concerning Assistance to Islamic Boarding Schools, Islamic boarding schools are categorized as: (a) Islamic Boarding Schools type A, namely Islamic boarding schools which are all carried out traditionally; (b) Islamic Boarding School type B, that is Islamic Boarding School which conducts classical teaching (madrasab); (c) Boarding School type $\mathrm{C}$, that is boarding school which is only a boarding house, while the students study outside; (d) Type D Islamic Boarding School, that is, Islamic Boarding School operates a boarding school system and at the same time a school or madrasah system. ${ }^{23}$

\section{Overview of the History of al-Achsaniyyah Islamic}

\section{Boarding School}

The existence of a pesantren is not just born, but often because of the various things that surround and demand its existence. Likewise, al-Achsaniyyah Islamic Boarding School, where it arose or was established because of a large commitment to practice their knowledge with the community. And there are demands for the development of society and the level of thought of science, and the future in life. Al-Achsaniyyah Islamic Boarding School was established because of the struggle and basic ideas that were consistent with the level of knowledge possessed and a great responsibility for the fate of the nation and the next generation.

${ }^{23}$ R. Hartono, "Pola Komunikasi di Pesantren: Studi Tentang Model Komunikasi antara Kiai, Ustadz, dan Santri di Pondok Pesantren TMI al-Amien Prenduan," al-Balagh: Jurnal Dakwah dan Komunikasi, 2016. 
H.M. Faiq Afthoni Rahman, M.Ac.The MCH provides a rationale for why al-Achsaniyyah Islamic Boarding School was chosen. ${ }^{24}$

Al-Achsaniyyah Islamic Boarding School Foundation was established in 2007 on contract land in Mburikan area for approximately 3 years. At the beginning, the contract land was used as a place of general therapy for the surrounding community, by practicing Thibbun Nabawi knowledge he gained while studying at al-Azhar University. In addition to sick patients who are still considered normal, one of the patients is autism (ADHD), with daily therapy that he carried out, seeing the struggle of parents who are persistent with the healing of their children, in addition he also saw the condition of autistic children who are often underestimated in community, finally he was inspired to establish a special boarding school for autism. ${ }^{25}$

He was very concerned about the situation, where there were no Islamic boarding schools established for children with special needs, only therapeutic sites and SDLB, mostly non-Muslim movements. Finally, he decided to combine medical science with Islamic boarding school in the form of al-Achsaniyyah Islamic Boarding School as proof of his concern and knowledge. ${ }^{26}$

Most of the resources or surrounding communities initially ignored and did not respond to these desires well. indifferent and trivial looking at the Islamic Boarding School, some even thought there would be established therapies for crazy people. Therefore, the founders of the foundation strive to provide understanding and understanding of the community so that parents can develop the talents and interests that each child has. It is expected that after

${ }^{24}$ Interview with Yudhi, caregiver of the Islamic Boarding School Autis alAchsaniyyah on Sunday, September 5, 2019, in Pedawang Kudus.

25 "Pembelajaran Pendidikan Agama Islam pada Anak Autis di Sekolah Lanjutan Autis Fredofios Yogyakarta."

${ }^{26}$ I. Khusna, "Studi Kasus Penanganan Anak Autis Menggunakan Pendekatan Religi di Pesantren al-Achsaniyyah di Kabupaten Kudus" (Skripsi: Universitas Negeri Semarang, n.d.). 
getting therapy and education, children will be useful both for parents or the surrounding community. For this reason, caregivers of the foundation provide innovation and renewal for the community with the establishment of al-Achsaniyyah Islamic Boarding School.

In 2010 he got wakaf land given by his grandfather, intending to establish Islamic boarding school. The name al-Achsaniyyah itself is taken from the name of the land endowment, Mr. Achsan. By doing so, he did not forget his services and kindness in giving his waqf to become Islamic boarding school. ${ }^{27}$

The main reason al-Achsaniyyah foundation was established was for normal children, considering that he is also a graduate of Gontor Islamic Boarding School. The thought he reviewed recalled the number of autistic patients in the surrounding community. Parents who have special needs children from the community or one of their patients who are considered less able to handle either medically or educationally. ${ }^{28}$ Also, in the community itself children. those with special needs are still considered to have no life skills, life goals, and a good future. from time to time, people who initially did not care much about the Islamic Boarding School began to believe after the development of success and progress in therapy, the community began to trust to entrust their children to al-Achsaniyyah Islamic Boarding School. ${ }^{29}$

In 2012 al-Achsaniyyah Islamic Boarding School received recognition and support from various parties. Both from the community, family, Department of Education. With a special boarding school, children with special needs are considered to be able to help alleviate them from the less decent life.

\footnotetext{
${ }^{27}$ Bandi Delphie, Pendidikan Anak Autis (Yogyakarta: KTSP, n.d.).

${ }^{28}$ S. Adriana. Ginanjar, Kiat Aplikatif Membimbing Anak Autis (Jakarta: Yayasan Mandiga, n.d.).

${ }^{29}$ R.M. Syaifullah, "Islam dan Disabilitas: Peran Kyai dalam Transmisi Nilai-nilai Tentang Anak Autis: Studi Kasus di Pondok Pesantren Autis al-Achsaniyyah Kudus” (Tesis: Universias Gadjah Mada Yogyakarta, n.d.).
} 


\section{Kyai/Caregiver and Teacher of al-Achsaniyyah Islamic Boarding School}

Kiai is known as a teacher or main educator as well as a physician in Islamic boarding schools. So-called because kiai in charge of providing guidance, direction, and education to the students. It is also kiai who are the ideal figures of santri in the process of personal development, although in general kiai also has several assistants or better known as "ustadz" or "santri senior". Kiai, in a general sense, is the founder or leader of an Islamic Boarding School. He is known as an educated Muslim who devotes his life solely in the way of Allah by exploring and disseminating Islamic teachings through educational activities. Al-Achsaniyyah Islamic Boarding School is under the care of Mr. H.M. Faiq Afthoni Rahman, M.Ac. MCH is a Thibbun Nabawi Islamic medical practitioner who studied at Pondok Modern ar-Risalah Ponorogo, Pesantren Tambak Beras in Jombang, al-Azhar University Cairo specialist in Islamic medicine at ICC el-Guiza Egypt and continued at Faculty of Homeopathy Malaysia. ${ }^{30}$

Syaifullah's research results ${ }^{31}$ state that kiai/leader of the pesantren has an important role in spreading values about how to view children with disabilities positively. The important role of kiai in transmitting values must be maintained and developed by involving many actors involved in it.

While the teachers and staff at al-Achsaniyyah Islamic Boarding School are helping to succeed in all the planned programs and trying to realize the goals to be achieved. Teachers and employees play an important role in the lives of students (children with autism)

${ }^{30}$ Interview with Yudhi, caregiver of the Islamic Boarding School Autis alAchsaniyyah on Sunday, September 5, 2019, in Pedawang Kudus.

${ }^{31}$ R.M. Syaifullah, "Islam dan Disabilitas: Peran Kyai dalam Transmisi Nilai-nilai Tentang Anak Autis: Studi Kasus di Pondok Pesantren Autis al-Achsaniyyah Kudus", (Tesis: Universias Gadjah Mada Yogyakarta, n.d.). 
where every day for 24 hours, they are the ones who serve and help the needs of children so that they also know the extent of child development.

Teachers and employees at al-Achsaniyyah Islamic Boarding Schools are usually divided into two groups (morning and evening shifts). Morning shifts are usually filled by special school teachers, one-on-one teachers, secretaries and treasurers of the foundation as well as some cleaning and kitchen staff. While night shifts are usually filled by boarding division, some employees and night guards. The teachers and employees of al-Achsaniyyah Islamic Boarding School generally come from Kudus, but there are also those from outside the region such as Jepara, Demak, and Rembang. ${ }^{32}$

\section{Santri al-Achsaniyyah Islamic Boarding School}

In contrast to other pesantren that have santri under normal circumstances, al-Achsaniyah Islamic Boarding School only accepts santri. By experiencing disabilities especially autistic children and those with special needs. In this lodge, students are classified into two, namely students who are still in elementary school and students who are adults (aged 15 years and over). The classification is intended so that the learning received is not the same, but adapted to the needs of children. For example, students who are still in elementary school are taught academic skills such as reading, writing, and so on. While adult students are taught sewing, communication, and socializing skills with the community.

The students in Islamic Boarding School do not only come from the city of Kudus, but also different cities. Some of them are mostly from Kudus, Jakarta, Bandung, Bekasi, Malaysia. The origins of santri from their families also differed, some from well-to-do families, some from orphan families, there were also du'afa'.

${ }^{32}$ Interview with Yudhi, caregiver of the Islamic Boarding School Autis alAchsaniyyah on Sunday, September 5, 2019, in Pedawang Kudus. 
Santri in al-Achsaniyyah Islamic Boarding Schools mostly come from holy areas, but many also come from outside the holy areas such as Pati, Demak, Tuban, Bekasi, East Jakarta, Cirebon, Lampung, and some even from Malaysia. With the concept of Islamic Boarding School, students from various regions must live in Islamic boarding school. Living in a dormitory is a prominent feature in pesantren education. At al-Achsaniyyah Islamic Boarding School santri are classified into three levels, namely pre, intermediate, and independent. The classification is intended so that the learning received is not the same, but learning is tailored to the needs of children. For the problem of new santri (pre), it is usually observed in advance one month or two months and in the process of observation is monitored by one student and one teacher, after being monitored, then they are grouped. The number of students in al-Achsaniyyah Islamic Boarding School is 98 students.

\section{Al-Achsaniyyah Islamic Boarding School Infrastructure}

Infrastructure is a factor that determines the success of an education. With the fulfillment of adequate infrastructure, it will facilitate the achievement of optimal teaching and learning activities. That is because following the function of the infrastructure itself, namely as a component referred to as a boarding school and as a support for teaching and learning activities. The supporting infrastructure such as building mosques, dormitories or huts and schools or madrasah.

The mosque is an inseparable element from pesantren and is considered the most appropriate place to educate the students, especially in the practice of the five daily prayers, Friday sermons and prayers, and the teaching of classical Islamic books. Since the time of the Prophet Muhammad, the mosque has been a center of Islamic education. Muslims always use mosques for places of worship, meetings, centers of education, administrative, and cultural activities. The position of the mosque as a center of education in 
the pesantren tradition is a manifestation of the universalism of the traditional Islamic education system.

The boarding school or residence of students is a hallmark of pesantren tradition which distinguishes it from other education systems. 4 local buildings are used as dormitories at al-Achsaniyyah Islamic Boarding School Kudus.

The supporting infrastructure in education is built by an extraordinary school (SLB) under the name SLB Sunan Kudus in al-Achsaniyyah Islamic Boarding School Kudus. Special education is held in the morning. However, there are a small number of students who also attend schools outside the hut because of their better development than other students. The education process is carried out every Monday-Friday.

The curriculum used at al-Achsaniyyah Islamic Boarding School is a combination of the curriculum from the Department of Education with a curriculum designed by the Islamic Boarding School. Each child will be given a different curriculum depending on the ability of the child and the will of the parents. In al-Achsaniyyah Islamic Boarding School, cooperation between parents and Islamic boarding school is very necessary to find out what needs are needed by children. Before the child enters the boarding school, the cottage collects information and identifies it according to the child's needs. After gathering information, the boarding school communicates this to parents and makes curriculum decisions as to what will be given to children. Remembering every autistic child has different needs according to his ability level. The curriculum is capitalizing behavior that reflects good morals and daily worship. ${ }^{33}$

That the implementation of the curriculum at al-Achsaniyyah Islamic Boarding School is essentially the same as other schools because they both adopt a curriculum from the government. However, the difference is that the curriculum must be adapted

${ }^{33}$ Abdul and Zakaria, "Pondok Pesantren: Changes and Its Future." 
to the abilities of children, as well as in the implementation of the PAI curriculum. Even though the children who are cared for at al-Achsaniyyah Islamic Boarding School are in the teenage category, sometimes their behavior is the same as that of children in elementary school. ${ }^{34}$

Given the ability of children with autism is not the same as other normal children, the implementation of the curriculum is also slightly different from public schools. Like the determination of religious education material, here the boarding school gives full freedom to the teacher to take control of learning both in terms of determining the material and what methods the teacher will use in working on the material. ${ }^{35}$

In determining the material following learning planning, that learning material to be provided must be following the needs of children. In terms of material, the material that is more emphasized on children is the concept of God, that is by introducing the child to who God is and applying the concept of God in daily practices such as the practice of prayer and getting used to applying morality in the daily life.

In the process of learning religious education in al-Achsaniyyah Islamic Boarding School students are taught many things, such as prayer, Qur'an, reading, and learning to write. Learning methods for autistic children are different from normal child learning methods. Based on observations and interviews, al-Achsaniyyah Islamic Boarding School uses ABA/Lovaas method. ${ }^{36}$

\footnotetext{
${ }^{34}$ Firdaus, "Model Pembelajaran PAI Inklusi pada Peserta Didik Autis di SDLB Sunan Kudus."

${ }^{35}$ Ina Zulia A. Yulisetyaningrum and R.M. Anny, "Hubungan Dukungan Sosial dengan Kemampuan Sosialisasi Anak Autisme di Yayasan Pondok Pesantren ABK alAchsaniyyah Kudus Tahun 2017," Jurnal Ilmu Keperawatan dan Kebidanan 9, no. 1 (n.d.): $44-50$.

${ }^{36}$ Firdaus, "Model Pembelajaran PAI Inklusi pada Peserta Didik Autis di SDLB Sunan Kudus."
} 
ABA/Lovaas method is done employing subject matter about thaharah ( $w u d u$ ) by demonstrating or showing the child about the ablution process while giving instructions to children to hold members who need to be washed in wudhu. However, if there are children who do not give any response the teacher comes to him and gives instructions once again by asking the same thing, if students still do not respond then the teacher or therapist helps direct the child and show the face/face. This is done until the wudhu process is completed. After all students respond well, the teacher or therapist says "good" as a positive reward, then the teacher gives bread to all children so that the child is more enthusiastic in learning. ${ }^{37}$

In addition to being taught ablution, children are also taught to write, read, pray, pray and read Qur'an. For example, to give instructions to children to write their names, they can write correctly, but when researchers give instructions to write other than the child's name still can not.

As for prayer learning, the teacher or therapist first introduces prayer readings such as takbir, reading al-Fatihah letters, reading short letters and so on. Learning will be repeated until the child really can and memorize prayer readings. ${ }^{38}$ After the child can then the teacher or therapist continues with the practice of the prayer movement. The teacher gives examples of movements in advance to the child while reciting the prayer readings. After the teacher practices, the students are instructed to imitate the prayer movement according to what they see with the help of the teacher or therapist.

\section{Conclusion}

Based on the explanation above it can be concluded that the al-Achsaniyyah Islamic Boarding School is a boarding school that

${ }^{37}$ Bandi Delphie, Pendidikan Anak Autis.

${ }^{38}$ Nuranisah, "Pelaksanaan Metode Applied Behaviour Analysis untuk Pembelajaran Anak Autis di Pondok Pesantren al-Achsaniyyah Pedawang Bae Kudus Tahun 2015" (Tesis: STAIN Kudus, n.d.). 
has unique characteristics, where it is more concerned in caring for and educating students who have special needs, especially in children with autism.

As with other Islamic Boarding Schools, al-Achsaniyyah Islamic Boarding School has several components such as kiai, santri, dormitories, mosques, and madrasah as educational institutions. The presence of clerics occupies an important position other than as a leader, caregivers as well as physicians or people who have healing skills. While students in al-Achsaniyyah Islamic Boarding School are students with special needs, this condition is what distinguishes it from other huts which usually have normal conditions in terms of ability. With students who have needs that demand different implementation of education as well. Therefore, in al-Achsaniyyah Islamic Boarding School, the educational institution is an extraordinary school.

This research is a small part of an effort to see how Islamic Boarding Schools develop dynamically in facing various changes and adjusting the needs faced by Muslims. Therefore, several studies can be developed as an extension of this study, such as economic issues and the commodification of autistic students, education management in autistic boarding schools and religious approaches in the treatment of autistic children. 


\section{REFERENCES}

Abdul and Zakaria. "Pondok Pesantren: Changes and Its Future."

Abdul, Gamal and Nasir Zakaria, "Pondok Pesantren: Changes and Its Future," 2016.

Adriana, S. Ginanjar, Kiat Aplikatif Membimbing Anak Autis. Jakarta: Yayasan Mandiga, n.d.

Blanks, J.D. and A.B. Smith, "Multiculturalism, Religion, and Disability: Implications for Special Education Practitioners, Education, and Training in Developmental Disabilities," 44, no. 3 (2009).

Delphie, Bandi. Pendidikan Anak Autis. Yogyakarta: KTSP, n.d.

Departemen Agama RI Direktorat Jenderal Kelembagaan Agama Islam. Pondok Pesantren dan Madrasah Diniyah. Jakarta: n.d.

Firdaus. "Model Pembelajaran PAI Inklusi pada Peserta Didik Autis di SDLB Sunan Kudus."

Firdaus, U. "Model Pembelajaran PAI Inklusi pada Peserta Didik Autis di SDLB Sunan Kudus". Skripsi: UIN Walisongo Semarang, n.d.

Ghaly, M. "Islam and Disability: Perspectives in Islamic Theology and Jurisprudence". Leiden University, 2008.

Haningsih, Sri. "Peran Strategis Pesantren, Madrasah, dan Sekolah Islam di Indonesia," 2008.

Hartono, R. "Pola Komunikasi di Pesantren: Studi Tentang Model Komunikasi antara Kiai, Ustadz, dan Santri di Pondok Pesantren TMI al-Amien Prenduan," al-Balagh: Jurnal Dakwah dan Komunikasi, 2016.

Hatab, T.A. and M.S. Bazna, "Disability in the Qu'ran: the Islamic Alternative to Defining, Viewing, and Relating to Disability," Journal of Religion, Disability, and Health, n.d.: 5-24. 
Herman, H. "Sejarah Pesantren di Indonesia," al-Ta'dib, 2013.

Interview with Yudhi, caregiver of the Islamic Boarding School Autis al-Achsaniyyah on Sunday, September 5, 2019, in Pedawang Kudus.

Jamaluddin, M. "Metamorfosis Pesantren di Era Globalisasi," KARSA: Journal of Social, 2012.

Khusna, I. "Studi Kasus Penanganan Anak Autis Menggunakan Pendekatan Religi di Pesantren al-Achsaniyyah di Kabupaten Kudus". Skripsi: Universitas Negeri Semarang, n.d.

Makmun, H.A.R. "Pembentukan Karakter Berbasis Pendidikan Pesantren: Studi di Pondok Pesantren Tradisional dan Modern di Kabupaten Ponorogo," Cendekia: Jurnal Kependidikan, 2016.

"Manajemen Pendidikan Inklusif: Konsep, Kebijakan, dan Implementasinya."

Muhakamurrohman, A. "Pesantren: Santri, Kiai, dan Tradisi," IBDA: Jurnal Kajian Islam, 2014.

Mustaqim, A. "Menggagas Pesantren Transformatif," Aula, no. 9, (n.d.).

Nuranisah. "Pelaksanaan Metode Applied Behaviour Analysis untuk Pembelajaran Anak Autis di Pondok Pesantren al-Achsaniyyah Pedawang Bae Kudus Tahun 2015”. Tesis: STAIN Kudus, n.d.

"Pembelajaran Pendidikan Agama Islam pada Anak Autis di Sekolah Lanjutan Autis Fredofios Yogyakarta."

Rispler-Chaim, V. Disability in Islamic Law. Dordrecht, The Netherlands: Springer, n.d.

Shapiro, A.H. Everybody Belongs. UK: Routledge, n.d.

Sunardi and Sunaryo. "Manajemen Pendidikan Inklusif: Konsep, 
Kebijakan, dan Implementasinya," Jurnal Asessmen dan Intervensi Anak Berkebutuban Khusus 10, no. 1 (2011): 184-200.

Sutrisno, B.H. "Sejarah Walisongo: Misi Pengislaman di Jawa," 2007. Syaifullah, R.M. "Islam dan Disabilitas: Peran Kyai dalam Transmisi Nilai-nilai Tentang Anak Autis: Studi Kasus di Pondok Pesantren Autis al-Achsaniyyah Kudus". Tesis: Universias Gadjah Mada Yogyakarta, n.d.

UNICEF, "The State of the World's Children with Disabilities", Executive Summary, in https:/ / violenceagainstchildren.un.org/ sites/violenceagainstchildren.un.org/files/documents / other_documents/sowc_2013-executive_summary_en_.pdf.

White, P.J., M.J. Jackson, V. Gordon. "Implicit and Explicit Attitudes toward Athletes with Disabilities," Journal of Rehabilitation 72, no. 3 (n.d.): 33-40.

Yulisetyaningrum, Ina Zulia A. and R.M. Anny. "Hubungan Dukungan Sosial dengan Kemampuan Sosialisasi Anak Autisme di Yayasan Pondok Pesantren ABK al-Achsaniyyah Kudus Tahun 2017," Jurnal Ilmu Keperawatan dan Kebidanan 9 , no. 1 (n.d.): 44-50. 